Open Access

\title{
The social grounds of anticommunism in South Korea-crisis of the ruling class and anticommunist reaction
}

\author{
Dong-Choon Kim
}

Correspondence: dckim@skhu.ac.kr SungKongHoe University, Seoul, South Korea

\begin{abstract}
I focused on how the domestic social grounds of anticommunism were interlinked with the external atmosphere like U.S. occupation, divided state-building and the Korean War. I especially emphasized the role of the Japanese collaborators in the post-colonial politics. Anticommunism as a political ideology surrendered to anticommunism as a rationale for the survival of class interests when historical task of overcoming colonialism was dominated by the Cold War atmosphere and full scale war. When North Korea's threats came to reality by the outbreak of the Korean War, hysteric style of anticommunism came to dominate the other forms of anticommunism. The chronic occurrence of anticommunist hysteria may be explained by the political landscape. It was not just the result of U.S. occupation force's policy, the international Cold War, but of the failure of de-colonization, by which former Japanese collaborators became the hegemonic groups among Korea's anticommunists, left dark shadow on South Korea's politics.
\end{abstract}

Keywords: Anticommunism, Cold War, Japanese Collaborators, Liberalism, Korean War

\section{Prologue}

The Cold War is a chronic war-preparation system against the possible aggression of an enemy. Like other ordinary wars, the Cold War also had supposed the real threat of enemies both within and outside, it had dominated not only the external relations of a country, but also internal policing, systematic surveillance against the 'designated internal enemies'. Its goal was securing lasting safety by eradicating anti-state thoughts and activities in a country. At the height of Cold War, both the Soviet Union and the United States stigmatized even simple political dissidents as 'traitors' who were suspected to serve the enemy. The 'red hunt', the white terror in America and the Stalin's massive punishment of the dissidents were the tragic outcome of the extreme Cold War ideology ${ }^{1}$.

Anticommunism for the Western world was and has been both an outward and inward expression of the Cold War. Especially, anticommunism was a chronic 'enemymaking' project toward the internal dissidents and extremities that try to annihilate the targeted domestic social and political group, person (Raskin 1976; Robin 2001). In America after the Russian Revolution of 1917, communism was condemned for unpatriotic stance and betraying American values and institutions. It was also denounced for

(C) The Author(s). 2017 Open Access This article is distributed under the terms of the Creative Commons Attribution 4.0 International License (http://creativecommons.org/licenses/by/4.0/), which permits unrestricted use, distribution, and reproduction in any medium, provided you give appropriate credit to the original author(s) and the source, provide a link to the Creative Commons license, and indicate if changes were made. 
its atheism. Businessmen exploited anticommunism to crush unions, fundamental preachers used it to summon the faithful while Anglo Americans used it limit immigration. ${ }^{2}$ Sparked as reaction against the Russian Revolution, anticommunism became an international phenomenon of the Western world from the Cold War period from 1945 to 1989 when the United States engaged in ideological rivalry with the Soviet Union. In alignment with the U.S's anticommunist policy, other countries in the capitalist world shunned communism. South Korea, divided by the occupation of these two mega powers, was situated at the frontline of the Cold War.

Anticommunism on the Korean peninsula was originated from the period of Japanese colonial rule (1910-1945), especially from the time of Sino-Japanese war (1937-1945). It was officially inaugurated in 1948 when the divided governments were established in North and South of the Korean peninsula, which led to massive political violence before and during the Korean War (1950-1953). As the heated confrontation between the U.S. and the Soviet Union energized frantic anticommunism in America under the McCarthyism, South Korean politics was intensified by the national division and the Korean War, which could be viewed both as an internalization of the Cold War and the continuation of political conflict among Koreans after the 'liberation'. With the collapse of Soviet Union and the end of the Cold War in 1989, anticommunism in the Western world lost ground. But the anticommunist movement in South Korea outlived after 1989 as an anti-North Korean ideology.

South Korea's anticommunism appeared mainly as a state ideology while anticommunism elsewhere has been officially or unofficially initiated and supported by political parties and social forces intermingled with fascism, liberalism, or social democracy. South Korea's anticommunism was actualized as a state-led physical violence like mass killing, torture, terror and political exclusion which intended for annihilating domestic enemies who had been suspected of collaborating with external 'enemies'. As a national identity, anticommunism in South Korea has been formed through harrowing experience of the Korean War, and defensively defined by the very presence of its enemy, North Korea. But the state-led anticommunism reflected the economic, political and social crisis that the ruling class faced after the Japanese surrender.

Thus, the long-duration and strength of South Korea's anticommunism can't be easily explained by its specific geo-political, historical conditions within which it has been situated. The domestic social and political forces that have exploited the South Korean's nightmarish experience should be considered. The scope or danger of 'internal and external enemies' that the ruling class confronted and their subjective sense of crisis resulted in the intensity of South Korea's anticommunism. The production and reproduction of anticommunism in South Korea may be related the birth and situation of its ruling class.

Like the United States in its heyday of anticommunism, 'nationalist' organizations, anti-union bourgeois and the religious fundamentalists sustained the fight against communism at home (Leffler 1994:59). But, as a post-colonial state, South Korea's anticommunism had unique social groundings. I will clarify this point. In this article, I will highlight the main social groups that contributed the growth of anticommunism, and what historical experiences or interests made them so extreme anticommunist. Since red-baiting and xenophobia seem to be built-in components of South Korea, understanding its politics and the nature of conflict between the two Koreas requires looking through the prism of lasting anticommunism. 


\section{South Korea's anticommunism as ideology, law, institution, and practices}

Anticommunism is a political ideology, an official belief, and a part of the massive psychology of the ordinary South Koreans, into which collective interests of the ruling elites of South Korea are condensed. It is concentrated on the National Security Law and institutionally practiced by such intelligence agencies like CIC (Counter Intelligence Corps), public prosecutors, Korean Intelligence Agency (KCIA, now renamed Special Intelligence Service) and special police units. Furthermore, it has been equated with national identity, basic doctrine of state, and the principles of diplomatic line of South Korea but also the political system or social order. We can also explain the fundamental structure of political conflicts and the patterns of dissident movements in contemporary South Korea from the work of anticommunism. In contemporary South Korea, anticommunism, have served as an indispensable weapon for protecting the nation against the threats of North Korea's communism and the symbolic logic of national division as an extreme internalization of Cold War. ${ }^{3}$

Some liberal democratic countries after 1945 turned anticommunist states with the intensification of international Cold War, but it usually remained as a subordinate ideology to liberal democracy in terms of each country's constitution, governmental practices and the ideology of political parties. In South Korea, however, anticommunism as a state ideology, overwhelmed the newly introduced principle of liberal democracy. Some articles of the National Security Law, which was passed December 1, 1948, just when Yeosun (Yeosu, Suncheon) rebellion broke out, ${ }^{4}$ could threaten the very essence of the Constitution by which the logic of liberal democracy could be guaranteed. ${ }^{5}$

In 1986, there was a dispute over what is the Korea's 'core state policy'(Kuksi Nongang). When a National Assemblyman, You Sung-whan, argued that South Korea's core state policy was 'national unification' rather than anticommunism, he was convicted for violating National Security Law. Even though the court finally decided he was innocent, the episode demonstrated that anticommunism reigned as supreme ideology or doctrine that even a National Assemblyman could not challenge it. ${ }^{6}$ In this sense, anticommunism in South Korea's context was more a religious dogma than just a policy or political ideology. Like a feudal religion, anticommunism could force every South Korean citizen to voice their stance of anticommunism or confess whether they had once involved anti-state activities. It was not only a cultural pressure but also a kind of symbolic violence. ${ }^{7}$

Especially, Korea's anticommunism appeared as a chronic red-scare, or hysteria against the political dissidents even after the ceasefire of 1953, which was seen in America in around 1918 or 1950 when the socialist revolution or apparent aggression of the North Korean communism panicked American ruling class and public (Kovel 1994: $15-22) .{ }^{8}$ As an ideologically and militarily divided country, South Korea has been situated in 'state of war' technically with North Korea. Under such a condition as North Korea would bring down the South Korea's government, and North Korean 'spies' or internal 'traitors' plot a rebellion, massive political propaganda with designed project of 'fabricating fear' propelled or conditioned campaign for 'spy-hunting, spy-searching and unrestrained arrest, detention and torture against those who were suspected as 'internal enemies'

While red-purge in America and other western countries in the heyday of the Cold War lasted only for several years in the 1950s and the political repression on the 
communists didn't develop into massive political violence, anticommunism in South Korea legitimized state violence and developed into civil war around 1948, which lead to maddening mass killings even before the full scale war. Outbreak of the Korean War of June 25, 1950, ushered spread of mass killings across the Korean peninsula (Kim 2004, 2007). On the ideology of anticommunism, mass killings against the suspected communists were unleashed. And the South Korea's Gwangju massacre in 1980 committed by the new military group led by Chun Doo-whan could occur in the sequence of anticommunist state terror that initiated in 1948.

Anticommunist rhetoric has frequently been used whenever the South Korea's ruling classes faced deadly political crisis on the attack of internal opponents. Even after the collapse of military regime of 1987, which was then followed by the fall of the really existed socialism and European Cold War, anticommunist discourse in South Korea was reinvigorated on the surge of the labor strikes and the social movements. The Cold War anticommunism transformed itself into anti-North Korea ideology following the transition from the Cold War to neo-liberalism. Instead of the Soviet Union, North Korea has been stigmatized and ridiculed by Western media after 1989. The collapse of Soviet Union did not cause the disappearance of anticommunism in South Korea because of lasting national division and military confrontation between the two Koreas. But as the failure of the communist system proved to be an apparent reality, antiNorth Korea ideology replaced the Cold War anticommunism since then.

Anticommunism, in South Korea, was the 'functional equivalent' of 'racism' in Western countries for the ruling class needed scape goats for securing their vestige interests. "The Red" signified a half-human who was to be despised, suppressed and even exterminated. ${ }^{9}$ As Korea is a highly homogenous country in terms of race, culture, and language, the Japanese colonial rule could not resort to the divide and rule strategy that other European imperialism applied to Asian and African, multi-ethnic, multi-religious, colonial territories. Japanese imperial forces exploited instead the existing social cleavages among Koreans between elites and commons, Christians and non-Christians, and landlord and peasants. Especially, the Japanese tried to win over well-educated elites, Christians and landlords among Koreans, who thus came to collaborate with the Japanese colonial rule especially after the Sino-Japanese War, while suppressing the activities of nationalists and communists. The independence activists regarded Japanese collaborators as 'anti-nationalist traitors' who should not be pardoned for by any reason. In retaliation, colonial officials branded 'nationalists and socialists' as 'communists'.

The reason why anticommunism lasted so long as a dominant ideology in South Korea may be explainable to national division and the 'de facto' war since the ceasefire of 1953. If both Koreas didn't plunge into civil war in 1950 and reached a peace system on the peninsula, South Korea's anticommunism might have lost its ground. But the objective condition may not be the exclusive variable in explaining its existence; because some ideologies can outlive its founding conditions for functional reasons. These ideologies root and work so far as ordinary public accept and embrace them based on their own experience or by public education. Extremism also reflected from their fear of being exposed for their past crimes. Thus, it is crucial to understand the political and social backgrounds of the South Korean ruling groups after the August 15, 1945, to explain the character of South Korea's anticommunism. Knowing which groups in South Korea, on what grounds and reason, acclaimed or clung to anticommunism after 
the collapse of Japanese colonial rule may be the first step in understanding South Korea's anticommunism.

\section{Basic conditions for anticommunism in South Korea: the allied forces' divided occupation, the Cold War and the Korean War}

The victory of the Allied Forces in the World War 2 brought a divided occupation of the Korean peninsula by the United States and Soviet Forces alongside the 38th parallel. Following the Japanese surrender, the south of the parallel was commanded by General John R. Hodge, whose missions were to disarm the Japanese troops, maintain order, and "establish orderly government of Korea below the 38th parallel". U.S. occupation forces were pressed to use the Japanese administrative machine, especially the Korean police force, for the efficient administration and to control demonstration and riots incited by Korean nationalists and communists.

And the U.S. Army Military Government in Korea (hereafter USAMGIK) also found that the Soviet-sponsored socialist reformation had launched in North Korea even though the U.S. and Soviet Union occupied Korea on military expediency. Their divided occupation turned eventually into the consolidated national division, and internal conflict over ideologies, capitalism and communism, finally developed into the civil war, and the full scale war, the Korean War. The official proclamation of anticommunism and the initiation of the Cold War in international level, the Truman Doctrine of 1947, were preceded by the United States' occupation forces and subsequent USAMGIK's anticommunist policy since September 1945 which campaigned to fight domestic communism from its initiation. In this sense, the Korea preceded the Western world in terms of launching the 'red scare' or the Cold War by plunging into the 'hot war' in 1950 (Kwon 2010). It was the extreme of ideological confrontation and, simultaneously, a stepping up to a different sphere (Lauterback 1947:353).

By the divided occupation, the Korean peninsula was situated at the front line of the global Cold War, which led to the one of the hottest conflicts, the Korean War, in the 20th century. And all Koreans suffered the most tragic disaster after 1945 and the have been suffering from the de facto war, national division as a chronic war-preparation system, even after the ceasefire of 1953. With Taiwan in East - Asia, anticommunism as 'emergency' and 'red-purge' has dominated South Korea's domestic politics for longest period in the world. We cannot find more appropriate place than Korea where the Eric Hobsbawm's term of 'The Age of Extremities' can apply (Hobsbawm 1994).

But the left-right ideological cleavage among Koreans originated in the 1920s under the Japanese colonial rule. Then, the younger generations among the Korean independence movements leaned toward socialism and communism encouraged by the Russian Revolution of 1917. After 1919's March 1 mass demonstrations, Korean national independence movements came to be divided into struggle-first line and conformism over the strategy for liberation. The former argued that only struggle against the Japanese imperialism would bring independence while the latter thought that using Japanese-installed institutional machines and educational opportunity could bring Koreans emancipation from colonialism. The former line was mainly supported by young intellectuals acquainted with socialism and anarchism while older generations and Christians stood on the latter line. From the mid of 1920s, conflict over the strategy for independence from the Japanese colonialism became intensified between the 
nationalists and communists. But the Imperial Japan's all-out war system in the late 1930s left no room even for the conformists to say nothing of radical line.

The looming ideological division among Korean elites came to fore on the Korean peninsula when Japan surrendered to the U.S. and allied forces on August 15, 1945. The disputes over long-aspired state-building, of economic and political systems, were heated among Koreans. The communists aspired to build communist country, but nationalists and liberals, some of them Christians, supported the U.S. style capitalist system. But the divided military occupation by the U.S. and Soviet forces, even though it was a sudden decision, proved to have serious political impact on the divided Koreas. General Hodge, as a military commander of the United States Armed Forces in Korea (USAF) made decisions on every political task in close coordination with local military commanders who had never heard of Korea before. For the political cause, they began to strengthen the forces of the rightists regardless of the instruction from Washington.

Finally, in 1948, two divided governments were established on both sides of the 38th parallel. South Korea's new born Rhee Syngman government panicked by the Yeosun rebellion of 1948. Exploiting the suppression policy on the Yeosun rebellion, South Korean intelligence organization tracked down and punished 'internal enemies' in the Korean military. Experiencing the incident, South Korean military confirmed the anticommunism as a basic principle and imbued it to all soldiers. ${ }^{10}$ Finally, on facing the real threat of internal communists in the Jeju and Yeosun rebellions, the newly born Korean National Assembly passed the National Security Law into which the cause of anticommunism was concentrated. Domestically, the Jeju April 3 uprising, the Yeosun rebellion, and finally North Korea's invasion in June of 1950 furnished the rationale of anticommunism for South Korean ruling elites. Since, South Korea has been the most belligerent anticommunist country (Noe 2008: 204).

It is said that the end of the World War 2 brought the collapse of fascism globally. But whether Japan's surrender made Japan truly democratic country, or whether 'fascist' components of East - Asian countries were removed seemed doubtful. In contrast with the West European countries, the U.S. - led post-World War 2 politics in East - Asia failed to remove the old fascist or imperialist forces in Japan, which was typically demonstrated in the amnesty on the war criminals Tokyo tribunal. Eventually in Japan and South Korea, old fascists or extreme rightists, who led and supported the totalitarian regime after the Sino-Japanese war, reentered the power bloc under the cover of 'postwar' democracy (Bix 2001). The U.S. planned to make Japan its semi-colony in containing Soviet Union and China in East - Asia on which exoneration of war criminals and to build anticommunist system were needed. ${ }^{11}$ As the fascist rule in Nazi's Germany and Imperial Japan before 1945 stood firmly on anticommunism, ${ }^{12}$ the U.S. support Japan's Tenno system and pardoning war criminals after World War 2 in East - Asia meant the continuation of past anticommunism in East - Asia.

The historical fascism of the first - half of the 20th century was also anticommunist, which was a kind of reaction of the bourgeois or ruling classes on the fear of socialism and labor movements. Anticommunist fascism showed a sense of crisis of the bourgeois, which was a defensive resolution against the potential threats whatever they plot or design. In terms of anticommunism, there was no fundamental rupture between the Japanese colonialism and the U.S. - led Cold War in East Asia. Especially in post - colonial South Korea, U.S. occupation forces administered 
on the logic of maintaining status quo, which was quite different from their democratization policy in Japan.

\section{Several social grounds of South Korea's anticommunism}

\section{Class interests and Japanese collaborators' necessity for survival}

Hearing the news of Japan's surrender on August 15, 1945, the leftist independence activists were the most active in responding the 'good news'. They organized Preparation Committee for State-Building and the Peoples' Republic, which were the most popular political organizations just after the 'liberation'. But some Koreans who had collaborated with the Japanese colonialism as bureaucrats, policemen, military officers, businessmen and intellectuals were intimidated and remain immobile for a few weeks. They looked for political groups by which they could be saved from possible imprisonment or punishment. The Korean Democratic Party (Hanguk Minju-dang), the first conservative party after 'liberation', appeared on September 8, 1945. It openly proclaimed that "we put the project of removing 'the Preparation Committee for Establishment of State”, "the Peoples' Republic' first".

The KDP's fast establishment was an expression of Japanese collaborators' and conservatives' counter-attack on the left-led Preparation Committee for State-Building and the Peoples' Republic. From the beginning, KDP proclaimed its identity as a party for countering the leftists (Ho 1979:110). The KDP, leading figures of which were Kim Sung-su, Back Kwan-su, Kim Byung-ro, Jang Dugk-su, Kim Jun-yeon, Jang Taek-sang, seemed to be lifesavers of the Japanese collaborators. The leaders were conservatives or revisionist nationalist, most of whom had taken compromising stances with the Japanese colonialism. The educational background of the 70 leaders of the party was college graduates, and $47 \%$ studied in Japan and $27 \%$ studied in America. And $75 \%$ of them were affiliated with professional class like doctors, lawyers, or freelancers. Openly announcing the struggles against the communists, the party received the money of proJapanese businessmen and landlords who were desperate to preserve their property. The KDP defended the interests of the high bureaucratic officials and police officers under the Japanese colonial rule in an attempt to counteract the Peoples' Republic and other leftist leaders (Han 1974:12) As they used to be during the colonial era, their class interest was more detrimental than the national cause or public values.

Because of their class position, landlords and capitalists were highly obsessed on their vestige interests and antagonistic against communism that denied private property. They were mostly power oriented elites who had been willing to collaborate with foreign forces to safeguard their professional status and material interests. Officially, they announced their "support the Provisional Government in Shanghai" among various groups of overseas national independence movements, but they were ready to endorse any rightist political leaders who could protect them; Rhee Syngman in America was regarded as the most believable guardian for them. They felt threatened by the surge of communists because communists criticized most on their past activities as 'traitory' (Shim 1982:119-125). ${ }^{13}$ The nation-wide conflict over the trusteeship in December 1945 marked the turning point when those wealthy classes and former Japanese collaborators, who were criticized as 'national traitors', presented themselves as 'patriots' in the anti-trusteeship demonstration. ${ }^{14}$ Massive movements against the trusteeship 
signed at the Moscow's there Summit Conference in December 1945 marked the turning point for former Japanese collaborators, landlords, end rightists elites to transform themselves as anticommunist 'patriots' in contrasting themselves with the communist 'traitors' who obeyed 'Soviet Imperialists'. They saw the Soviet-occupied North Korean territory as a colony and North Korean as a subjugated 'slave' under communist dictatorship.

They expressed an uncompromising anticommunist stance openly from early 1946 when USAMGIK negotiated with the Soviet Union occupation forces over the establishment of Joint provisional government in South Korea. They convinced the U.S. military commanders that the dialogue with the communist would be futile. Jang Taek-sang, Cho Pyung-ok, who took the top post of the national police, supported the returned Rhee Syngman from the U.S. and used the metaphor of 'being satellites' in their relation with him because Rhee could keep their interests from the attack of the communists. So they thought it was a 'life and death problem' to establish an anticommunist government even though it would be a divided one. They refused any compromise with the communists with regarding them as 'enemies'. They stance on communism was similar to hysteria.

Japanese collaborators and the wealthy classes in South Korea had very apparent reason to support the KDP by any means in order to secure their status and property from the threat of communists and nationalists. The USAMGIK, an occupation government, played the decisive role in reviving those Japanese-trained bureaucrats and ruling elites. Land reform was the central policy issue at that time. The KDP endorsed "appropriation by compensation, and distribution with pay", which contradict the communist land reform policy, "Appropriation without compensation, distribution for nothing". The KDP opposed the communist policy because it denied the principle of private property. It was the natural response of the KDP because the policy was to protect their members' and sponsor' interest. Since then, the KDP made little efforts to solve the national division by North-South dialogue or to seek détente. Instead, they have promoted a policy of no compromise with the communists.

As political scientist Shim Ji-Yeon said, the most crucial impact of the KDP on South Korean political culture would be anticommunism (Shim 1982). It is quite paradoxical that the KDP's anticommunist stance engendered South Korea's basic state policy thereafter, which was founded to defend the country against the 'political enemy' over the issue of trusteeship without other core principles and platforms. The appearance and sustenance of the KDP was generally an expression of the interests of intimidated Japanese collaborators', land lords' although some liberals and moderate intellectuals joined it on their political thought and philosophy.

Even though ordinary people' rising demand of punishing pro-Japanese elites was very high just after August 15, 1945, USAMGIK ignored the public will by rehiring them in main posts based on the necessity of administration and then on waging Cold War against the communists. Those elites took main posts in the newly established South Korean government in 1948 with the firm support of the first President Rhee Syngman. But they could not secure their positions when the Special Committee for the Investigation of Collaborationist Activities against the Nation (hereafter Special Committee) was finally established in 1949. It appointed a special judge and a special prosecutor to carry out the preparatory investigation of collaboration and to enforce the special law (Chung 2002). 
If the Special Committee was successful, most of the top-ranked officials in the military and police were destined to lose their positions and were likely to be punished (Noe 2008:224-231). But the Special Committee was established in tandem with the 'national emergency' caused by the Jeju April 3 uprising and Yeosun rebellion. A panicked South Korean government campaigned for searching leftist segments in the military and purging them. Thus, newly elected President Rhee obviously ordered to sabotage the work of the Special Committee in the name of campaigning for leftists' rebellion. Finally he proclaimed that "we should pardon the national traitors" (Japanese collaborators) by providing them with an opportunity to serve the nation, which meant that the struggle for anticommunism was the paramount excuse for restrengthening Japanese collaborators in South Korea.

When this Special Committee was disabled by the attack of President Rhee, Japanese collaborators, the KDP and other anticommunist right-wingers, the military criminalized the progressive politicians in the National Assembly by fabricating the espionage case. The military arrested a group of National Assemblymen who had opposed passing the National Security Law of $1948,{ }^{15}$ which was regarded as a continuation of the Japanese Security Maintenance Law of $1925 .{ }^{16}$ The South Korean G-2 and military police might fabricate the incident under the direction of politicians. But, throughout the sequence such incidents, the South Korean military discarded its original oath that it would keep a neutral position, and openly acted as an anticommunist political force.

The mood of anticommunism was most ardent among those who served the Japanese intelligence agency whose mission was to track down the Korean and Chinese antiJapanese independence activists under Japanese colonialism. Kim Jong-won and Kim Chang-young, who had worked in the notorious Japanese intelligence agencies, stood at the frontline of anticommunist 'crusade', with openly proclaiming "any segment of communism should be eradicated" It was a xenophobic psychology of self-protection against communist attack. As equivalent to the war criminals in Japan, they thought only a U.S. sponsored anticommunist regime could protect them. Anybody who dared to criticize them would to be branded as communist.

\section{Anticommunism as political line, thought and activities-liberalism, Christianity and} fascism

\section{Liberalism and liberal leaders}

Japanese colonial rule permitted the freedom of religion and social activities of the Christian leaders while suppressing socialist movements because Imperial Japan's ruling system, the Tenno system and the Security Maintenance law, the backbone of which was punishing the anti-system thought and safeguarding the principles of private property, was basically grounded on anticommunism.

Some Korean elites who praised liberal democracy and human rights during the Japanese colonialism thought that Koreans could achieve independence through education, media, and economic capacities instead of resorting to 'reckless' armed struggles against colonialism. After Japan's surrender, fast activation of the leftists in August 1945 prompted the immediate reaction of the liberals and nationalists, which was the establishment of the KDP. Most of them had wealthy family backgrounds and careers of overseas studies in Japan and America. Examples were Kim, Sung-su, Song Jin-u 
who studied in Japan, and Jang Duk-su, who studied in America. Rhee Syngman's close friends like Lee Gi-bung, Cho Pyung-ok, Jang Taek-sang, Ho Chong, Louise m were the notable figures among them. ${ }^{17}$

Most of the elites studied in the U.S. returned to Korea after August 15, 1945. By experiencing the U.S.'s way of life, they were accustomed to the western liberal thought and individualism. Trained in the American universities and U.S. academism, they thought that the raison d'etre of state was the fulfillment of individual interests. And because of their wealthy family backgrounds, they were mostly liberal in their manner or habituated to a bourgeois way of life. And they took an anticommunist stance naturally thinking that "the socialist strategy should be absolutely abandoned because historical materialism and communism cannot be an alternative for so solve complex issues in such a radical measure, and the social progress can be achieved by revising it one by one". ${ }^{18}$

Those U.S. educated elites who returned to Korea before the 'liberation' engaged in educational jobs like teachers, professors, missionaries or social workers. Some of them were involved in moderate nationalist movements or took an adaptive attitude toward Japanese rule. Because some of them stayed in America throughout the colonial period, they could keep relatively a good image, as opposed to elites living in Korea who had little choice but to collaborate with Japanese colonial policy and Sino-Japanese War. Even though they were anticommunist in political orientation, it couldn't be expressed openly because ideological cleavage among Koreans were subordinated to more pressing and superior cause of national independence and national independence movements, in which the communists had played the crucial role, had undisputable moral authority for all Koreans.

Shortly after the "liberation, these liberal elites joined the KDP, which was believed to represent their social and political position. In the first political principles of the KDP, we can find articles that "we try to enhance the welfare of working people", and "main industry should be nationalized", but interestingly we can't find some articles that "we oppose socialism". It is because that there remained some rooms for left-right compromise in the political vacuum left by Japan's surrender even though they supported a liberal democracy and were critical of any kind of socialist alternatives. And the KDP's 'official' political line reflected the general political atmosphere of the post-colonial period when leftists enjoyed a more favorable reputation than rightists, most of whom collaborated with the Japanese.

While we can guess that the family backgrounds of the KDP members and other national independence activists might affect each of their political line, several conflicts with each other over the strategy toward the national independence was not less important factor in their position taking. As Japanese colonialism had already removed the traditional mode of production and the feudal status system, late developed Korean middle class or liberals did not combat feudalism. Moreover the historical time of the growth of Korean liberalism, by the Japanese economic policy of permitting modern companies in Korea, coincided with the growth of communism after 1917. This is the historical background why Korean liberals and nationalists took anticommunist position through the confrontation with communist independence movements rather than through struggles with feudal despotism. Especially, in the postcolonial era, their standpoint and identity was mainly formed and concretized through harsh contest with the communists over the mechanics of state-building. 
The national division and the start of socialist reformation in North Korea forced liberals and nationalists to migrate to South Korea. With the intensification of the ideological struggles between the right and the left, some moderate socialists and social democrats converted to rightist political group and eventually joined the Rhee's government. They did so out of fear observing the consequences of Kim Il Sung's regime and South Korea's communist party led by Park Hun-young. Even though they embraced the ideal of social democracy, Cold War and national division left little room for them to keep their ideas and policy. Liberalism and social democracy had ever surrendered anticommunism since the Russian Revolution the Great depression. ${ }^{19}$ The liberals and social democrats in Europe collaborated with the fascist-led anticommunist campaign. The Japanese political system before and during World War 2, Japanese 'all-out war system, which may be called Asian style fascism, and colonial domination system sidelined liberals. Even by the U.S. occupation policy of 'liberating' Korea from the Japanese fascist rule, Korea's political culture created by pre-modern war and Japanese colonialism changed little after 1945.

Unlikely to the same divided country like West Germany, political space in which liberals and social democratic elites present their ideas and policy alternatives could not be created in South Korea by the extreme antagonism between the two divided Koreas. Since some principles of liberal democracy were easily ignored even in West European countries at the height of the Cold War, ${ }^{20}$ it would not be surprising that even liberals as well as moderate social democrats could not survive in South Korean politics. South Korean liberals and social democrats forced to rescind their political thought to anticommunist on the threat of North Korea's communism. If the Korean War didn't break out, we could find some liberals or social democrats in South Korean politics.

\section{Christianity and Christian leaders}

The USAMGIK, uninformed about the Korea's social and political situation, was heavily dependent on the advice of American educated Christian leaders with good command of English. In terms of anticommunism, the U.S.'s national interests coincided with those of church because the latter did not tolerate atheism and communism. Thus USAMGIK's mobilization of Christians in administration was an expression of American policy in the Third World where the Christian missionary had long acted as the vanguard of the U.S.'s interests. The General Douglas Macarthur, who was a devout Christian, considered the post-war democratization of Japan the same one as Christianization, a principle on which the USAMGIK's policy was executed (Kang 1996, 2007). Of the 19 members of the Korean interim Legislative Assembly in 1946, the number of professing Christians was 21, including seven ordained missionaries (Kang 1997:75).

But long before the U.S. occupation, Korean Christians had been anticommunist in their political orientation. From the 1920s under Japanese colonial rule, the Korean Christians had kept antagonistic stance against growing communist movements. Sociologically, it was the understandable for the middle-class Christians to rally against the working-class oriented communists who were encouraged by the success of the Russian Revolution and, then, proclaimed atheism. In the debate over the path to Korea's independence, the compromising attitude of the Christians with the colonialism was strongly criticized by Marxist revolutionaries. In addition, the influence of the American missionaries should be considered in explaining Christian anticommunism. 
As U.S. protestant missionaries in Korea were mostly evangelical in their religious propensities, they discouraged Korean Christians to participate national independence movements (Yi 2011). In the 9th General Committee of the Korean Christians in 1932, the 12 principles for social activity were officially proclaimed, which included their opposition to "any materialist education, materialist thought, class struggle, and social reformation by revolutionary means", and "reactionary suppression on us". On these principles, they regarded anticommunism as a kind religious doctrine, as anti-atheism. Thus, most Christian leaders generally took the position of anticommunism as their religious cause.

After August 15, 1945, the Christian leaders supported Rhee Syngman, who was also devout Christians and a well-known U.S. educated rightist. When political confrontation between the left and the right was ignited over trusteeship issue, the anti-trusteeship camp was mostly mobilized by the Christian base. ${ }^{21}$ Around 1946, many North Korean Christians leaders crossed the 38th parallel in order to find shelter from the North Korea's anticommunist policy on Christianity, which contributed the intensification of conflict between the communists and Christians (Kang 2004). The anticommunist stance of Christian leaders from the North could also caused by their middle or upper class background (Kang 2005:45).

From then, the Protestants and Catholics came be characterized as bulwarks of anticommunism in South Korea. Especially the commemoration ceremony of the March 1 Independence Movement in 1946 was separately held both by leftists and rightists. They paraded in the street of Seoul after the ceremony, but finally clashed, and unleashed violence against each other. As most of the Christian leaders attended the service of the Japanese Shrine during the 'all-out war' situation of the Japanese colonialism, the communists called them pro-Japanese or 'national traitors'. That hostile manner of the communists enraged the Christians and turned them into extreme anticommunists.

Throughout the anti-trusteeship movements around early 1946, Christian leaders called U.S.S.R.-led communism as "imperialism" and regarded South Korean socialists as anti-nationalist or just puppets serving the Soviet Union's 'imperialist conspiracy'. Thoroughly following the U.S. initiated Cold War ideology, they reversed their position by identifying their policy as uniquely formed by a 'national conscience. ${ }^{22}$ We can see the term 'nation' or nationalism was used in the opposite way by South Korean anticommunists. Those liberals and conservatives including Christian elites, who had served Japanese rule in violation of the 'national cause', transformed themselves into representatives of the 'nation'. After experiencing the Korean War, the Korean Christians called communists 'devils' or 'Satan', ${ }^{23}$ and defending South Korea's anticommunist regime was equated with Christian salvation (Kang 2005:47).

The 'black and white' logic of anticommunists had strong affinities to Christianity's dichotomy of 'good and bad' as the latter tends to see communism as an absolute evil. Anticommunists usually thought communism as a pathogenic bacterium that should be exterminated. South Korean Christians accepted the establishment of the Rhee-led anticommunist South Korea as a historical necessity that God designed. The tragedy of the Korean War was regarded as God's test for Koreans who should destined to suffer in order to accomplish God's will.

As Korean Christianity contributed much in the struggle against communism during the Korean War, the certificate of Christian (church membership) used for guarantee 
'South Korean citizenship' at the checkpoints or capitalize the names POW's camp in Koje. Rhee Syngman government gave some advantage to the Christianity by institutionalizing military pastor system and designating the church as the exclusive organization for distributing the U.S. aid materials. These beneficial policies gave Christians a pivotal role in the cultural or psychological war against communism.

The Korean Catholic also contributed much in consolidating anticommunism in South Korea. The famous Korean Catholic bishop Roh Ki-nam, who had also collaborated with Japanese colonial rule, was requested by the General Hodge to recommend the 60 elites who were required to play some crucial roles in Korean politics just after August 15, 1945. He gave the list of conservative Korean leaders to General Hodge. And he presided over the service for the U.S. military in Myungdong temple (Kim 2010 : 74). They urged the Catholics to participate the anticommunist crusade with the spirit of martyrdom and argued that "we should demolish the red demon's attack in order to make Korea perfect democratic country because the communists openly communize Korea". Later he could take over Kyunghyang Daily from the USAMGIK, which represented the anticommunist media at that post-colonial period. Raising the case of Manchuria and Peking that Maoists captured, he announced that "we may not enjoy the freedom of religion if communism will dominate Korea". When the Korean War broke out, he said that "we should fight to the end and annihilate any components of communism". Korean Catholics saw the War as a Crusade for defending freedom of religion and Christianity (Kim 2010:88).

After the war, there occurred several new Christian denomination sects. Their doctrines were mostly based on apocalyptic salvation and also expressed strong anticommunism. The Unification Church was such an organization. The Unification Church symbolized Korea's anticommunism and prided themselves as forerunners of anticommunism and pro-Americanism. Along with other Protestants, it emphasized that U.S. and South Korea was one body and the U.S. was almost equivalent to God. They positioned themselves as bulwarks of global communism by demonizing communism. Those Korean Christian leaders even amazed Westerners in the World Christian Council (WCC) conference of 1955, when communist Chinese Church applied for admission to WCC, by announcing that "we cannot coexist with communism because they are global imperialist” (Kang 2007:77.)

The anticommunism of Korean Christians repeated the American conceptions of 'freedom' and highlighted the difference between 'freedom' and 'slavery' in communism. The South Korean Christians' viewpoint was nothing more than an internalization of American Cold War cultural policy, building a 'spiritual-industrial complex'(Herzog 2010). ${ }^{24}$ Christianity, the U.S. thought, was the most powerful weapon in the struggles against communism. For the Korean Christians, Rhee Syngman's despotic rule and prevalent poverty in the 1950s were portrayed as a 'land of freedom' in contrast to North Korean 'slavery'; two confronting political systems were viewed by a religious worldview.

\section{Conservative nationalists and quasi-fascists}

From the Japanese colonial era, the Korean conservatives who had embraced the Confucian values, traditional way of life and cultural nationalism was critical to socialism in general. Conservative nationalists that regard the national community as an eternal or universal unit for human life were antagonistic to any kind of liberalism and 
socialism. Independent Movements activists, the leading figures in the Korean Provisional Government of Republic of Korea (KPG) in exile, who returned to Seoul after the 'liberation', were representative of that kind of Korean nationalist movements. ${ }^{25}$

The KPG was originally established in 1919 and adopted Republicanism and liberal democracy as founding ideology. Thus it had long opposed the communist independence movements over the strategy against Japanese colonialism. Conflicts in the Korean independence movements in the Shinganhoe (1927-1931) ${ }^{26}$ and Korean Provisional Government in China, emerged over class background of landlord class or the Confucian way of thought. Nationalist leaders who worked in China tried to build a united front with the communists, anarchists and radical nationalists. But they were finally spilt due to ideological difference and their nationalist strategies, between armed struggles and cultivating national capacity for future independence. Kim Ku, Cho So-ang, Shin Ik-hui and other old generations took the moderate line, while young generation leaders like Kim Won-bong supported military struggles against Japanese colonialism. The latter sympathized with communists while the former took generally anticommunist stance.

After August 15, 1945, they aspired to build Pan-National United Front under the leadership of Korean Provisional Government, but, eventually, their design was disrupted by the ensuing left-right confrontation, political terror and assassination of rightist leader Song Jin-u.who opposed the anti-trusteeship movements (Kang and Suh 2013), KPG members, who regrouped themselves into the Korea Independence Party in 1945, led the anti-trusteeship demonstration with Rhee and KDP, which developed into the anticommunist camp in South Korea.

Among the Korean Independence Party members, Jo So-ang, who was a famous thinker for the "Theory of Three Equality' and opposed the left-right coalition, kept stubborn anticommunist position because, he thought, communism denied national solidarity for the cause of working class solidarity. The anticommunist stance of the conservative independence activists during Japanese rule continued to exist after August 15, 1945. They regarded leftists in the post-colonial period as 'national traitors' who stood for the benefits of the Soviet Union and international socialism. Their anticommunism put them in lining with Rhee at the early days of the post-Liberation period. But as they embraced the ideal national unification first, they could not accept the Rhee's strategy of establishing South Korea's separate government even though they collaborated with him under anticommunist slogan. Thus, they abstained to participate in the general election of 1948 by which the South Korean government was scheduled to be established, this alienated them from the ruling bloc of South Korea. When Kim $\mathrm{Ku}$, the leader of the Korean Independence party, pursued the South-North dialogue and pleaded for national unification in 1948, he was branded as pro-communist by the extreme rightists and President Rhee, and he was eventually killed by extreme rightist in 1949. South Korea's anticommunism couldn't tolerate even the nationalist who had devoted themselves in the national independence movements. ${ }^{27}$

In the post-colonial period, some leaders had fascist propensities. Lee Pom-sok, who participated in the independence movements in China and An Ho Sang, who studied in Nazi-ruled Germany, would be the representatives of that category. As they criticized liberalism, individualism and parliamentary democracy, 'nation' and 'blood' were highly valued as in Hitler's Germany. Yi Pom-sok had a close relationship with the Chinese 
nationalist government, including Chiang Kai-Shek. In organizing National Youth Corps, which was often compared to Hitler's Jugend Brigade, he raised the slogans 'nation first', 'state-first'. Especially An Ho-sang criticized capitalism or democracy like early Hitler. Their thought influenced President Rhee's political ideology, which developed finally into Rhee's 'One Democracy Doctrine'. These extreme rightists often put emphasis on the 'organic theory of the state' and the role of heroic leader, which would be similar to the Confucian teaching of Tao, traditional morality, and familism. They thought that both capitalism and communism were similar in pursuing money, but were different in their method. That rhetoric was originally used by German Fascists or Japanese extreme rightists (Suh 2005:87-88).

Yi Bom-sok embraced a typical imperialist logic of Darwinism that "the weak are the prey of the strong", and "a superior race could survive and a failed race faded away in history". But it was doubtful whether his imperial fanaticism could apply to colonial Korea. While those ultra-nationalist political leaders criticized capitalism in speech, but, in action, they supported private property system and suppressed labor union activities. They idealized a system that can make everyone self-employed or small petit property owners. When President Rhee uttered that kind of populist or anti-capitalist discourse, it was nothing more than a political tactic to win over the working class, peasants and other marginalized classes over to their side (Lee 1948:3-4). Could South Korea keep a nationalist independent stance from the superpowers in early Cold War politics? Could they oppose the U.S. - Soviet designed national division? Finally, they supported the establishment of a divided South - Korean government and never criticized the amnesty on the Japanese collaborators who betrayed the nationalistic cause (Lee 1948:.229).

Rhee's 'One Democracy doctrine', which epitomized their rhetorical 'nationalism', was a political strategy which tried to fill the vacuum of national security left by the pullout of the U.S. army and consolidating Cold War system. Historical fascism was viewed as a reaction of businesses and rightists facing the threat of socialism. In this sense, South Korea's ultra-nationalists or quasi-fascist thought was another expression of anticommunism. Since the political discourse of the ultra-nationalists had no social ground in post- colonial South Korea dominated by Cold War international politics, they were doomed to be exploited and finally discarded by Rhee.

\section{Anticommunism as political violence and psychological disorder: the Japanese collaborators and North Korean defectors}

South Korea's anticommunism was characterized not just as a political line or ideology but as harsh strong red-complex, red-baiting, hysteria, and a neurosis in expression and behavior. For the psychologist, complex is a mental unconsciousness of one person or group that is captivated on a thing without considering other part of things because of its negative image. In this respect, red-complex can be understood as a mental complexities of having horror against socialism and communism and, simultaneously, being humiliated by them.

In contemporary divided South Korea, socialism and communism are not just potential threat, but 'real' threat from the political entity of North Korea. Thus, the red-complex in Korea's context meant an attitude of exaggerating North Korea's threat and their left-wing sympathizers in South Korea, or having excessive horror and sense of humiliation based on distorted images of them. Those who are obsessed with the red-complex tended to 
think that North Korea and left-related figures should be removed by any means, which led to a psychology of absolute reliance on the U.S. by which South Korea could resolve its national crisis. The massacres and political violence against leftists and their sympathizers during the Korean War were the result of this anticommunist hysteria (Kim 2004).

The main reason why the former pro-Japanese bureaucrats, policeman and military leaders upheld a hysteric anticommunism in the post-1945 period was due to their history of collaboration with Japanese colonial rule. They were highly consciousness of their past misdeed on serving the Japanese aggression on other East-Asian countries, collaborating the Japanese-committed colonial violence and massacres against other Asian people including Koreans. When Japan surrendered, they were ready to excuse their action by any means and support any political leader if he protected them. The U.S. and Rhee, who furnished their ideological weapons for them, seemed trustworthy. This is why the Japanese collaborators followed Rhee and U.S.'s anticommunist line blindly. Then, anticommunism and rightist independence leaders were the best shield or guardian that could be used for counterattacking their enemies.

During the Japanese colonial rule, as any opposition against the Japanese was morally legitimized and praised among Koreans. But since the 1930s, communist movements were strictly repressed. It was only after 'the liberation' that communism could be spoken of publically. As the communist voiced openly the necessity of punishing the Japanese-collaborators, they were plunged into psychological insecurity on the threat of the communists. For the wealthy Koreans and Japanese collaborators, American occupation policy of anticommunism and the establishment of the KDP were signal of 'salvation'. They were ready to believe in whatsoever safeguard them. Thus, from the beginning in Korea, the ideological dichotomy between communism and anticommunism was created more from the ground which power could be trusted rather than from a policy alternative.

The Japanese collaborators successfully disguised and called themselves 'nationalists' by attacking leftists on the ground that the latter obeyed the Soviet-Union. While this paradox of the former Japanese collaborators and their anticommunism was made possible by American anticommunist policy, it was also energized by their instinctive desire for self-preservation, horror, and sustaining their political status. Thus, anticommunism in South Korea accompanied political violence.

The national division and the massive migration of North Koreans ignited South Korea's atmosphere of anticommunism. The image and attitude on communism of the North Korean defectors grew out of their experience of suffering in North Korea. For them, the North Korean regime was both an object of horror and hate. Their redcomplex was kind of neurosis strain that was based on a distorted image of communism, and includes a sense of horror (Kim 2009: 160). That may be called a kind of collective psychological disorder, which expressed an extreme sense of victimhood. North Korean defectors, especially, among the pro-Japanese landlords and Christian leaders, expressed that kind of symptom typically. In their anticommunism, enragement over the takeover of their property and the demonization of communists are intermingled. The aggressiveness and political violence they committed in the way of red-purge expressed their sense of deprivation, hysteria, and extreme sense of crisis (Jang 2007).

For the North Korean defectors, especially for the Christians, the immigration was conceived as the 'Exodus' in bible. The psychology of the defectors was to seek egoistic 
adaptation, which lead them to depend on power and exclude 'outsiders'. The North Korean defectors were basically refugees who aspired to return their home as soon as possible. In their mind, the feeling of repulsion by the North Korean socialist regime, sense of deprivation by the forced immigration from their home town, and forfeit of property have always been rooted deeply. Even though some of them could gain power and wealth in South Korea, they have still thought that they are deprived of everything and threatened by communists. The psychology of defectors always divides 'us' from 'them', which create 'outsiders' incessantly ${ }^{28}$.

Once such people as having psychological disorder like anticommunism took power as police chiefs, military commanders, and heads of media, derangement in executing law and administration occurred. In order to remove the presumed 'enemies', they would use a McCarthy style of red-purge or unrestrained violence in operating public power. The red-baiting, the fabrication of espionage, and state terror used by the South Korean ruling classes when they faced serious political predicament would demonstrate the specific characteristics of Korean anticommunism embedded psychological strains. Under a chronic state of confrontation and de facto war in the Korean peninsula, psychopathological anticommunism wasn't a temporary irregularities but as a chronic phenomenon ${ }^{29}$.

Massive political violence and massacres unleashed before and during the Korean War were expressions of anticommunism. For the North Korean Christian refugees, it was a kind of religious war like those appeared in the Medieval Europe. During the Korean War, when most South Koreans had suffered from North Korea's People's democratic rule, anticommunism was rooted in the mind of ordinary Korean people, especially middle class or petit bourgeois group, as a lived experience and social psychology. Since then, South Korean students took feeling of hatred and repulsiveness by the public education, broadcasting, media and movies (Kim 2009: 166).

Paralleled with racism in the Western world, South Korea's anticommunism is a form of cultural, ideological, and political domination by which superior group in a political society discriminate, exclude, cause pain, and even kill an inferior group by means of laws, institutions, and physical force. Under hysteric anticommunism, if a ruling group could brand dissidents or opponents as communists, it would be authorized that other social groups enact physical violence on the 'targeted group'. In this case, those forerunners of red-baiting may be praised as 'patriots'.

As a kind of psychological disorder, anticommunism may be called extreme narcissism because considering themselves as the center of a world while putting others at the periphery as 'enemies', With prejudice against their political opponents, even against the liberalists, they tend to exaggerated their power and thought of themselves as conscribed by the enemies. Anticommunists were captives of chronic threats from the enemy, losing subjectivity their integrity of mind.

\section{The failure of liberalism in South Korea: Rhee Syngman and Park Jung-hee}

South Korea's anticommunists have felt uncomfortable as far as it can fix double or triple locking system against possible invasion of North Korea and attack of domestic 'enemies'. Anticommunism has been materialized in South Korea's law, institution, administration, education and political practices. Although anticommunism as liberalism and individualism in itself was believed to be contradictory to totalitarianism, it tended to develop into totalitarianism, especially when a polity is situated in a state of war. ${ }^{30}$ 
As South Korea was put into technically at war with North Korea after the ceasefire of 1953, South Korean 'liberal' political regime has taken 'despotic measures' to protect its regime. South Korea as a 'national security state' had to resort to undemocratic way of rule if necessary.

For Karl Polanyi, fascism was the offspring and the crisis of liberal empires and 'democratic regimes'(Polanyi 1935). Especially, Polanyi viewed fascism as an inverted by product of nineteenth century imperialism and the myth of self-regulating market, and liberal democracy in Western European countries was the other side of same coin of fascism and colonial domination before the World War 2 (Polanyi 1957). Likewise this pre-war coincidence, Cold War liberalism in the post- World War 2 Western world accompanied the dictatorship and neo-Fascist rule in the Third World. Totalitarian components within the liberal democracy continued to exist both in America and the Third World as anticommunism after 1945. Fulbright called the McCarthyism "Tyranny without a Tyrant" when $60 \%$ of the American people had a generally 'favorable opinion' of the Senator McCarthy. ${ }^{31}$ South Korea's anticommunism at its peak before and after the Korean War under which political terror, torture, and massacres were unleashed was not an extraordinary one in this sense.

Korea's anticommunism also grew out of Japanese totalitarian elements in the mind of Korean liberals and nationalists. The liberals took hands with the totalitarianism as German fascism grew on the terrain where German liberals leaned to the retroactive thought of racism. The real meaning of 'liberty', 'democracy' that Korean anticommunists have used so often meant anti-North Korea and pro-America. This interpretation had nothing to do with the 'principled attitude toward the value of liberalism or democracy, and which has no consistent political line or policy contents.

In this sense, South Korea's anticommunism, like those countries during the Cold War, has been sustained by a defensive mentality. Sometimes, anticommunist leaders always emphasized the national cause, but they usually victimized the national interests and national sovereignty in their diplomatic relations with the U.S. For South Korea, liberalism and nationalism often remain as mere rhetoric that cannot be applied to real politics and policy consistently (Cho 1959: 141-142).

We may find some liberal intellectuals and nationalist leaders who could be consistently anticommunist in their thought and behavior, U.S. educated Christian leaders, some rightist independence activists like Song Jin-u, Cho Pyung-Ok. But the assassination of nationalist leader Song Jin- $u$ in the midst of anti-trusteeship campaign marked a turning point for the KDP to become more pro-Japanese, pro-landlord party, following the Rhee's line one-sidedly. With U.S. military occupation, the conflict between the left and right was intensified and there was little room for Korean rightists to be conciliatory to the leftists. But if national division, the Korean War, and de facto war among Koreans did not occur, South Korean liberal and conservatives would not be such stubborn anticommunists. There were some differences between those who embraced anticommunism in order to safeguard class interests, those desperately needing self-preservation, and those who embraced liberalism, nationalism.

Generally, specific characteristics of Korea's anticommunism are concentrated in President Rhee's career, thought and behavior. Rhee may be a personification of anticommunism in Korea. He was a devoted Christian, U.S. educated intellectuals, spent most of his time in the U.S. and born in North-west Korea. Even before he immigrated to America, he 
converted to Christianity and preferred America to Russia. After the Russian Revolution, he solidified his stance of anti-Russian and pro-American stance. When he returned to Korea just after August 15, 1945, he didn't reveal his anticommunist position because the political influence of leftists at the time was stronger than that of the rightists. He employed nationalist rhetoric saying that "we don't oppose communist party, but, rather than this, we oppose their anti-nation stance". But when ideological conflict in South Korea intensified, keeping pace with intensification of global Cold War, he announced that "reds should be arrested and killed without any consideration" He preferred to mobilize or exploit those Japanese collaborators in order to stabilize his power base in order to subdue power of the communists.

Rhee's anticommunist discourse and practice was just an internalization of America's policy on the Cold War rather than an expression of South Korea's national interests. However, U.S.'s strategy of ceasefire with North Korea in 1953 clashed with the Rhee's 'northward unification' strategy. Finally, Rhee's anticommunism was betrayed by the U.S.'s global Cold War policy of keeping the status quo. His anticommunism reflected the interests of South Korea's Christians, wealthy classes and Japanese collaborators, which was structurally accorded with U.S. dominance in Korea. So Rhee didn't follow the American line unconditionally and the U.S. also felt uneasy about Rhee's uncompromising stance with communists, which led finally to unseat Rhee in $1960 .^{32}$

Facing North Korea's 'aggression' on South Korea, the U.S. was regarded as a savior and South Koreans, who stood in the front line facing global communism, identified themselves as having a historical mission of becoming guardian of anticommunism. When South Korea's situation was interpreted by the Soteriology in Christianity, Rhee or South Korea's anticommunism got a status of religion by which Korean people could be saved from hell. It was an active adaptive attitude for Koreans to the U.S. - led global Cold War and National Division in the Korean peninsula like the Korean Christian leaders. Thus, Korea's anticommunists are simultaneously pro-Americanists (Kim 1992).

Park Jung-hee's anticommunism, which was expressed in the No. 1 pledge of the May 16's Coup of 1961, "We try to realize the anticommunism as a concrete one which was sustained only in form". It heralded the strategy of economic development and anti-labor unionism. At the turn of 1960s, the U.S. shifted its global policy from old anticommunism to an active strategy for developing the 'client' countries. Park's anticommunism, which included economic development plan and normalization of diplomatic relation with Japan, were also just an adaptive stance to the new U.S. led new Cold War policy. Park's yearn for modernizing South Korea was another form of anticommunism. Park's anticommunism as development strategy could be evaluated as more advanced compared to the Rhee's, which reiterated the negative aspect of communist society. But Park's strategy can be seen as a continuation of Rhee's anticommunism because it didn't include social values such as 'freedom' or 'democracy'.

\section{Conclusion}

The politics of anti-communism in South Korea since its "liberation from Japan until today are largely dependent on the national division and the Korean War as an internalization of international Cold War. But the Korean War also contributed the spread of anticommunism in the Western world by way of McCarthyism in America, which spread to Europe including West Germany. In this article, however, I focused on how 
the domestic social grounds of anticommunism were interlinked with the external atmosphere like U.S. occupation, divided state-building and the Korean War. I especially emphasized the role of the Japanese collaborators in the post-colonial politics.

The KDP's anticommunist policy developed the South Korea's basic state ideology thereafter, which held a defensive position against its 'political enemies' over the issue of trusteeship without having any independent or coherent viewpoints of their own. It was an expression of the Japanese collaborators', land lords' and capitalists' class interests. When anticommunism as a rationale for survival have dominated Korea's politics, the ideological diversification among liberals, social democrats or conservatives became almost meaningless. Under the blast of red-purge and 'hot war, even liberal anticommunists who supported national unification and liberal democracy failed to secure their position in politics. If the Korean War didn't occur, they might survive and played some role in politics.

Anticommunism as a political ideology surrendered to anticommunism as a rationale for the survival of class interests when historical task of overcoming colonialism was dominated by the Cold War atmosphere and full scale war. When North Korea's threats came to reality by the outbreak of the Korean War, hysteric style of anticommunism came to dominate the other forms of anticommunism. The chronic occurrence of anticommunist hysteria may be explained by the political landscape. It was not just the result of U.S. occupation force's policy, the international Cold War, but of the failure of de-colonization, by which former Japanese collaborators became the hegemonic groups among Korea's anticommunists, left dark shadow on South Korea's politics. When the cause of fighting against communists got priority, de-colonization and democratization project in South Korea should yield it as the systematic denazification in WestGermany was hindered (Széll 2015) In the name of 'liberal democracy', South Korea's ruling classes used Japanese-left pseudo - fascist methods of oppression.

South Korea's political history since the 1950s, when anticommunism came to dominate as supra-constitutional power, would be characterized as 'one anticommunism against another anticommunism' because no dissident political parties could doubt this dogma. Under the political landscape where even liberal democracy, social democracy as well as moderate socialism in general were branded as 'leftist', the political field could be filled with the only moderate anticommunists. Following the U.S.'s Cold War strategy, anticommunism, which constituted South Korea's social and political identity, also mobilized chronic fear against a 'demon' called a communist. South Korea's political culture has been similar to that of the U.S. where "the Communists became anyone who challenged the order of things in a progressive direction" (Kovel 1994:22; Delton 2003). As Scott Nearing stated "liberalism in America was a broken reed (Nearing 1972: 135), liberalism in South Korea a 'crushed reed' under the extreme anticommunism. Finally, Korea' politics couldn't reflect the real spectrum of civil society, daily grievances of the working class, peasants and other under classes.

With the development of capitalism, the growth of middle class, and the democratization, Cold War anticommunism has wakened little by little. But subject of anticommunism in South Korea, however, has seen little change. Even after the democratization of 1987, social groups from different political backgrounds, regions, social stratum, and religions have resorted to anticommunism to secure their status and interests. In this narrowed political terrain, the opposition parties, whose ideologies 
have been similar to those of the ruling party, expressed a little more liberalism or nationalism. The main opposition leaders had similar positions with the ruling party in terms of anticommunism. But in such political landscape where anticommunism was praised and the little ideological divergence was tolerated, the ruling party had great advantage in institutionalized political competition.

When the Korean peninsula's national division system is dismantled and the new progressive party gain significant seats in the National Assembly, anticommunism will surrender to political principles such as liberalism, social democracy and other progressive values.

\section{Endnotes}

${ }^{1}$ The McCarthyism even regarded liberalism as an avant-garde communism (Haynes 2000). In this sense, anticommunism was not an idea or thought, but rather a political strategy of the rightists. Anticommunism as an ideological weapon for waging the Cold War, it regard every political conflict as 'enemy and us' as Karl Schmitt mentioned (Schmitt 2005, 2007)

${ }^{2}$ The rhetoric and actions of the Bolsheviks ignited fear, revulsion and uncertainty in the U.S. (Leffler 1994:6). That kind of reaction might be general in the capitalist world.

${ }^{3}$ Besides the National Security Law, anticommunist law (1963-1979), Social Security Law, Security protection Law were a machines for executing anticommunism. And besides the official governmental organizations like public security prosecutors and surveillance police, there existed an emergency organizations like Center for Joint investigation Committee for Leftists, Center for public Security. And KCIA and National police also established a research center like Institute for National Security or Institute for Public Security.

${ }^{4}$ Just after the establishment of South Korean government in August 1948, a rebellion that took place in Yeosu, Suncheon, South Jeolla against the South Korean Syngman Rhee government, which broke out as a refusal against the government's order of suppression of the Jeju Uprising. See, https://en.wikipedia.org/wiki/Yeosu-Suncheon_rebellion

${ }^{5}$ While South Korea's Constitution stipulated main liberal democratic principles like freedom of expression, rights of individuals, they could be easily ignored when the National Security Law was operated in arresting the internal enemies in the name of national emergency. "In the name of security, the bill outlawed communism and provided for prosecuting Communists under definitions and instructions to the judiciary so vague as to encourage utilization of the judiciary by the executive to eliminate political enemies"(Henderson 1968:160)

${ }^{6}$ In the U.S. McCarthyism was estimated to damage the 'core value of America' (Schrecker 2004:1072), but, in Korea, anticommunism have functioned as a 'core state policy'.

${ }^{7}$ In Europe and America, there existed liberal anticommunists, leftwing anticommunist, anarchists and social democratic anticommunists like Sydney Hook, George Orwell, Irving Howe. http://en.wikipedia.org/wiki/Anti-communism

${ }^{8} \mathrm{McC}$ arthyism was to become the longest lasting and most widespread episode of political repression in modem American history precisely because of its diversity (Schrecker, 2004)

${ }^{9}$ Richard Hofstadter explained the lasting characteristics of American politics as 'paranoid style' (Hofstadte 1964). He used this concept in explaining the McCarthyism 
of the 1950s and the extreme rightists' behavior like Goldwater of the 1960s. The paranoid style express an psychological attitude of 'being angry' and 'fear', which regarded 'political opponents' as moral or religious 'enemy' who are to be finally exterminated. Paranoid is usually used with 'hysteria, which is called 'hysterical paranoid' or paranoid hysteria, when a ruling group underestimate themselves as 'minority, and overestimate the opponents who don't exist with a status of emotionally excited condition or lack of restraint and self-control.

${ }^{10}$ At the beginning of newly built state, South Korean military put nationalism as its basic principle, but it replaced them with anticommunism after the occurrence of Yeosun incident. It established the bureau of politics in the G-2 department. USMGIK that sponsored in building new Korea's Military opposed Korea's design of establishing the bureau of politics because of Military's political involvement, the Korean government finally executed it with the different name, the political education bureau.

${ }^{11}$ Orwell thought that fascism, as a degenerated continuation of capitalism, was linked to socialism - a grim distortion of or reaction to socialism (Orwell 1958). But Hayek argued that socialism as collectivism was a continuation of fascism not a reaction against the socialist trend (Hayek 1994:25).

${ }^{12}$ Japanese fascism during the Sino-Japanese War also grew from red-scare in their country and colonial territory. Japanese Tenno system targeted communism as unacceptable rebellious thought, which was expressed in the Security Maintenance Law of 1925. Those people who opposed the Security Maintenance Law were suspected as communists whether they were native Japanese and Koreans.

${ }^{13} \mathrm{Mo}$ Yun-suk was the typical person. She was a follower of the most famous novelist Lee Gwang-soo, who positioned himself anticommunism saying "Now we should be afraid of invasion of thought". Banminjok Munjae Yonguso(Institute for Anti-Nation Problem 1993: 64)

${ }^{14}$ The trusteeship was originally an idea of America. U.S. President G. Roosevelt thought it was necessary to educate Koreans for enlightened self-government on the model of U.S. trusteeship in Philippine. He proposed forty years of political tutelage for Korea in Cairo Conference. But the resolution of Moscow's 3 Powers' Conference was known to Koreans that the Soviet Union proposed the trusteeship in Korea. That news ignited anti-Soviet or anti-communist demonstration.

${ }^{15}$ https://en.wikipedia.org/wiki/National_Security_Act_(South_Korea)

${ }^{16}$ The law was enacted in 1925, revised (strengthened) in 1928, 1941, and finally abolished in 1945. Death penalty was introduced in 1928. The definition of illegal activities in this law was so ambiguous that anyone whom government considered undesirable could be arrested.

${ }^{17}$ Ho Chong first met Rhee in 1912 at the age of 16 at YMCA school. In which Rhee was a superintendent. Ho had worked with Rhee in the U.S. for more than ten years. Ho joined Rhee's cabinet in 1948 as Minister of Transportation (Ho 1979).

${ }^{18}$ Cho Pyong-ok said that,"as I was personally instructed from Prof. Sinkovich when I studied at Colombia about the essence of communism and its destructive nature, ... I guessed the South North dialogue doomed to fail (Cho 1959: 57, 192). Ho Chong said that "as I am a liberalist, I dislike most the rule and dominance-subordination relation, and refuse forced unity and wholeness (Ho 1979: 64) 
${ }^{19}$ After the Russian Revolution, liberalism clashed with socialism everywhere in the world. Russian revolution panicked western capitalists and anti-Bolshevism was institutionalized in the U.S. State Department (Leffler 1994:19). And the 1929's economic crisis casted doubt on the sustainability of market economy and brought a fascist response. The ideological division around the 1930s left little room for moderate alternative like social democracy

${ }^{20}$ Hobsbawm recollected that "the principle of freedom of expression did not apply to communists and Marxist views, at least in the official media. What made the rhetoric of Cold War liberals so intolerable was their conviction that all communists were simply agents of the Soviet enemy" (Hobsbawm 2002: 182)

${ }^{21}$ In Southern Korea after the 'liberation', right-wing youth groups were mostly led by Christians (Suk $1984:$ 69-72)

${ }^{22}$ Former communist Yang Han-mo, who converted to the right, defended himself saying that the Soviet Union's national policy for the colonial people was not liberating them but recolonizing them (Yang 1990 :213)

${ }^{23}$ In Christianity, the red color always symbolizes Satan.

${ }^{24}$ After the end of the World War 2, the church and state collaborated in their common desire to drive communism from America's sphere of influence. Religious figures effectively conflated ideological struggles and moral questions by equating the turmoil between East and West (Gaddis 1997:282) In order to fight communism, the U.S. Catholicism and C.I.A. entered into partnership to fight communism in Latin America (Gribble 2003 :535)

${ }^{25}$ On the simple nationalist cause, they criticized the leftists who turned their position suddenly from pro-trusteeship to anti-trusteeship. By this reason, they thought the leftists were the puppets of Soviet Union.

${ }^{26}$ Shinganhoe was a Korean's most important pan-national front against the Japanese colonialism in which nationalists and communists joined under the cause of national liberation. However, it was soon disrupted by the repeated conflict over the ideology and strategy.

${ }^{27}$ The incident showed that the U.S. - led Cold War removed not only communists but also nationalist in the post-colonial countries.

${ }^{28}$ Sense of One-body with the U.S. was expressed a pastor's prayer. "God in heaven is American's God, Korean's God, Syngman Rhee's God, and Mankind's God”(Kim 1963 : 85)

${ }^{29}$ It was similar to Obsessive-Compulsive Neurosis symptoms. See, https://en.wikipedia.org/wiki/Obsessive-compulsive_disorder.

${ }^{30}$ George Kennan, who was the initiator of U.S's global Cold War policy, spoke in the speech at the National War Collage. "In fact, totalitarian thought is embedded in each of our mind to some extent"(Gaddis 1997: 72)

${ }^{31}$ Fulbright saw the menace of McCarthyism within the context of American vulnerability to the tyranny of an unthinking majority (Meyer 1963: 19)

${ }^{32}$ Rhee was forced to resign by the student uprising in 1960 . But It has been known that the U.S. urged him to step down. 


\section{Publisher's Note}

Springer Nature remains neutral with regard to jurisdictional claims in published maps and institutional affiliations.

Received: 1 February 2017 Accepted: 6 April 2017

Published online: 24 April 2017

\section{References}

Banminjok Munjae Yonguso(Institute for Anti-Nation Problem. 1993. Chinilpa GusipGuin(99 Pro-Japanese), vol. 3. Seoul: Dolbegae.

Bix, Herbert. 2001. War Crimes Law and American Wars in the Twentieth Century Asia. Hitotsubashi Journal of Social Studies 33(1): 119-132.

Chan Su, Yi. 2011. "Gunbonjuk Gunbonjui rul Hanghayo" [Toward the Fundamental Fundamentalism]. Jonggyo Gyoukhak Yongu(Review of Religious Education) 35: 2011.

Cho, Pyong-ok. 1959. Na ui Hoekorok(My memories). Mingyosa: Seoul.

Chung, Youn-tae. 2002. "Refracted Modernity and the Issue of Pro-Japanese Collaborators in Korea". Korea Journal 42 (3): 18.

Delton, Jennifer A. 2003. Rethinking the 1950s: How American Anticommunism and the Cold War Made American Liberal. New York: Cambridge University Press.

Dong-Choon, Kim. 2009. The Unending Korean War: A Social History, Translated by Sung-Ok Kim. Larkspur: Tamil Vista.

Ellen, Schrecker. 2004. "McCarthyism: Political Repression and the Fear of Communism". Social Research 71: 4.

Gaddis, John Lewis. 1997. We now know: Rethinking Cold War History. N.Y.: Oxford University Press.

Gribble, Richard. 2003. CSC, "Anti-communism, Patrick Peyton, CSC and the C.I.A". Journal of Church and State 45(3): 535-558.

György, Széll. 2015. International politics of Cold War and West Germany's anti-communism as its internalized form.

Han, Sungjoo. 1974. The Failure of Democracy in South Korea. Berkeley: University of California Press.

Hayek, Friedrich. 1994. The Road to Serfdom. Chicago: University of Chicago Press.

Haynes, John Earl. 2000. "The Cold War Debate Continues: A Traditional View on Historical Writings on Domestic Communism and Anticommunism". The Journal of Cold War Studies 2(1): 76-115.

Henderson, Gregory. 1968. Korea:the Politics of the Vortex. Cambridge: Harvard University Press.

Heonik, Kwon. 2010. The Other Cold War. New York: Columbia University Press.

Herzog, Jonathan. 2010. America's Spiritual-Industrial Complex and the Policy of Revival in the Early Cold War". The Journal of Policy History 22(3): 2010.

Ho, Chong. 1979. Naeil ul Wihan Jungun(Testimonies for Tomorrow- Ho Chong's memoir). Seoul: Samtusa.

Hobsbawm, Eric. 1994. The Age of Extremes: The Short Twentieth Century, 1914-1991. London: Michael Joseph.

Hobsbawm, Eric. 2002. Interesting Times - A Twentieth-century Life. London: Allen Lane.

Hofstadter, Richard. 1964. The Paranoid Style in American Politics. New York: Harper's magazine.

In-Cheol, Kang. 2007. Hanguk-eui Gaehingyo-wa Bangongjueui [Protestantism and Anti-Communism in Korea]. Seoul: Jungshim.

Jang, Suk-Man. 2007. "Afghan Pinap Sataega Boyojun Hanguk Gaeshingy(Korea's Christianity from the events of Afghanistan Hijacking", HangHae Munwha.

Joel, Kovel. 1994. Red Hunting in the Promised Land: Anticommunism and the Making of America. New York: Basic Books. Kang, In-Cheol. 1996. Hanguk Gidokgyo-wa Gukgar Siminsahoe 1945-1960 [Christianity in Korea and the State Civil Society 1945-1960]. Seoul: Hanguk Gidokgo Yoksa Yonguso.

Kang, Wi Jo. 1997. Christ and Caesar in Modern Korea : A History of Christianity and Politics. Albany: State University of New York Press.

Kang, In-Cheol. 2004. "Protestant Church and Wolnamin: An Explanation of Protestant Conservatism in South Korea. Winter: Korea Journal.

Kang, In-Cheol (2005). Hanguk Gidokgyo BangongJui ui Hyungsung kwa Jaesangsan [Production and reproduction of Christian anticommunism in South Korea]. Yoksa Bipyoung(Critical Historical Review). 70:40-63.

Kang, Jung-In, and Hee-kyung Suh. 2013. "Kim Sung-Soo and Korea's Liberal democracy- The origin of Korea's conservative political Thought and its continuity", Hanguk Jeonchihak Hoebo. Korean Political Science Review 47(1): 3.

Karl, Polanyi. 1935. "The Essence of Fascism", Christianity and the Social Revolution. London: Victor Gollancz. Ltd.

Kim, In-seo. 1963. Mangmyung Noin Rhee Syngman ul Byunhoham(In Defense of Refugee Old man Syngman Rhee). Seoul: Sinangsangwhalsa.

Kim, Dong-Choon. 1992. "Hanguk Jungang gwa Bangong Juui Byunwha" [The Korean War and the Change of Anticommunism], Korean Sociological Association, The Korean War and the Change of the Korean Society. Seoul: Pulbit.

Kim, Dong-Choon. 2004. Forgotten War and Forgotten Massacre- The Korean War(1950-1953) as Licensed mass Killings. Journal of Genocide Studies 6(4): 523-544.

Lauterback, Richard. 1947. "Hodge's Korea". The Verginia Quarterly Review 23(3): 947.

Lee, Bom-suk. 1948. Minjok Gwa Chungnyun [The Nation and Youth], 1948((Takesi, Hugee, 2013, Fascism Gwa Jesam Sege Saieseo [Between Fascism and the Third Worldism], Yoksa Bipyongsa).

Leffler, Melvyn P. 1994. The Specter of Communism: The United Sates and the origins of the Cold War, 1917-1953). New York: Hill and Wang.

Meyer, Karl E. 1963. Fulbright of Arkansas: The Public Positions of a private Thinker. Washington DC: Robert B. Luce, Inc Noe, Young Gi. 2008. Hanguk Gun Ui Hyungsung Gua SungGyuk(The Formation and Characteristics of the ROK Army from 1945 to 1950). Seoul: Ph. D dissertation of Sung Kyun Kwan University.

Orwell, George. 1958. The Road to Wigan Pier. New York: Harvest/HBJ Book).

Polanyi, Karl. 1957. The Great Transformation. Foreword by Robert M. Maclver. Boston: Beacon.

Raskin, Marcus G. 1976. Democracy versus the National Security State". Law and Contemporary Problems 40(3): 189-220.

Robin, Ron. 2001. The Making of the Cold War Enemy: Culture and Politics in the Military Industrial Complex. Princeton:

Princeton University Press.

Schmitt, Carl. 2005. Political Theology: Four Chapters on the Concept of Sovereignty. Chicago: University of Chicago Press.

Schmitt, Carl. 2007. The Concept of the Political. Chicago: University of Chicago Press.

Scott, Nearing. 1972. The Making of a Radical - A Political Autobiography. New York: Harper Colophon book. 
Shim, Ji-Yeon. 1982. Hanguk Minju-dang yeongu(A study of Hanguk Minju-dang. Seoul: Uulbit.

Suh, Jung-suk. 2005. IImin Juoi Wa Fascism [One-Democracy Doctrine and Fascism]. Seoul: Yuksa Bipyoungsa.

Su-Ja, Kim. 2010. "Habang hu Roh Ki Nam Jugyo wa Bangong Ju ui: 1945-1953"(Pastor Roh Ki Nam and his Anticommunism". Hanguk Gyohoisa Yonguso, [Gyohoisa Yongu(A study of Church History) 35: 12.

Suk, Jung-Gil. 1984. Saebyuk ul Dalin Dongidul(Comrades who run at the dawn: A Short memory on the anti-trusteeship Student Movements in Daegu. Gabin Chulpansa: Seoul.

Yang, Han-mo. 1990. Joguk un Hana Yotda (Homeland was one). Seoul: IlmoGihok.

Submit your manuscript to a SpringerOpen ${ }^{\circ}$ journal and benefit from:

- Convenient online submission

- Rigorous peer review

- Immediate publication on acceptance

- Open access: articles freely available online

- High visibility within the field

- Retaining the copyright to your article

Submit your next manuscript at $>$ springeropen.com 